\title{
SIMULASI POLA OPERASI TAMPUNGAN EMBUNG TIU PASAI SEBAGAI SUPLAI AIR BAKU DAN IRIGASI MENGGUNAKAN METODE ALGORITMA GENETIK
}

\author{
Wahyu Sri Sardono ${ }^{1}$, Widandi Soetopo ${ }^{2}$, Very Dermawan ${ }^{2}$ \\ ${ }^{1}$ Mahasiswa Program Magister Teknik Pengairan Fakultas Teknik Universitas Brawijaya \\ ${ }^{2}$ Dosen Jurusan Teknik Pengairan, Fakultas Teknik, Universitas Brawijaya, Malang \\ e-mail: wahyusri@student.ub.ac.id
}

\begin{abstract}
ABSTRAK: Simulasi pola operasi pada tampungan Embung Tiu Pasai merupakan suatu rancangan dalam pemecahan masalah model perencanaan dengan batasan tertentu untuk menghasilkan keputusan terbaik dalam alokasi pemberian air dari Embung. Kebutuhan air Irigasi eksisting untuk areal irigasi \pm 5 ha dengan intensitas tanam $65 \%$ dan di harapkan dapat ditingkatkan menjadi 15 ha dengan intensitas tanam 100\% sekaligus mengalirkan debit 20 lt/dt untuk air baku. Tujuan dari studi ini adalah untuk mengevaluasi pemberian air yang paling optimal pada masing-masing periode untuk pemenuhan kebutuhan air baku dan irigasi dengan meningkatkan areal irigasi. Metode yang digunakan adalah simulasi dengan pedoman lepasan berdasarkan tampungan dengan algoritma genetik. Metode Algoritma Genetik dioperasikan menggunakan program spreadsheet Excel dari Microsoft Office versi 2016. Metode ini dapat meniru perilaku sistem dan dapat digunakan untuk membuat suatu keputusan dari serangkaian keputusan yang terkait. Hasil simulasi berdasarkan pedoman lepasan dengan Algoritma Genetik, terjadi limpahan (spillout) dengan total volume $42,930,250 \mathrm{~m}^{3}$, terjadi reduksi volume limpahan sebelum menggunakan pedoman lepasan hasil algoritma genetik dengan total volume limpahan (spillout) sebelumnya 44,537,417 $\mathrm{m}^{3}$, mampu meningkatkan intensitas tanam menjadi $100 \%$ dengan luas areal 15 ha dan mengalirkan 20 lt/dt untuk air baku. Sehingga Alokasi Pemberian Air dari Embung lebih optimal.
\end{abstract}

Kata kunci: Embung, Lepasan Berdasarkan Tampungan, Algoritma Genetik

\begin{abstract}
Simulation of the operating pattern in the Tiu Pasai Retention Basin reservoir is a design in solving the planning model with certain limitations to produce the best decision in the allocation of water from Reservoir. Existing Irrigation water requirements for \pm 5 ha irrigation area with 65\% cropping intensity and are expected to be increased to 15 ha with 100\% cropping intensity and supply $20 \mathrm{lt} / \mathrm{s}$ for Fresh water. This Research has a purpose of of evaluating the most optimum water supply of Fresh water and irrigation by increasing irrigation areas. The method used simulation Release rule based on Reservoir Storage with Genetic Algorithm. Genetic Algorithm method operated using an Excel spreadsheet program from the Microsoft Office 2016. This method is able to replicate the system and make a decision from a series of related decisions. The simulation results based on Reservoir Storage with Genetic Algorithm, total volume spillout $42,930,250 \mathrm{~m}^{3}$, there was an abundance volume reduction before using discharges result of genetic algorithm with total spillout of 44,537,417 $\mathrm{m}^{3}$ increase cropping intensity to $100 \%$ with an area of 15 ha and supply $20 \mathrm{lt} / \mathrm{s}$ for Fresh water. Which is makes water allocation allocation decisions more optimal
\end{abstract}

Keywords: Retention Basin, Release rule based on Reservoir Storage, Genetic Algorithm

Embung merupakan sarana infrastruktur sumber daya air yang berfungsi sebagai penyimpanan dan penyedia air. Air yang melimpah pada musim penghujan ditampung dan disimpan serta dimanfaatkan secara tepat guna, tepat waktu dan tepat sasaran sepanjang tahun.
Dalam memanfaatkan tampungan baik waduk maupun embung perlu dipertimbangkan bahwa kuantitas air sangat terbatas, sehingga pemakaian air harus sebaik mungkin. Untuk itu perlu dilakukan pengoperasian penggunaan air Embung yang optimal agar dapat memenuhi berbagai kebutuhan yang direncanakan. 
DAS Nangabangka pada studi masuk dalam wilayah iklim Tropik yang cenderung lembab, walau demikian, daerah ini lebih kering bila dibanding dengan daerah lain di Indonesia kecuali Nusa Tenggara Timur. Temperatur maksimum berkisar antara $30^{\circ} \mathrm{C}-$ $33^{\circ} \mathrm{C}$ dan temperatur minimum berkisar antara $20^{\circ} \mathrm{C}-25^{\circ} \mathrm{C}$. Kelembaban relatif tinggi yaitu antara 40\%-100\% (Balai Wilayah Sungai Nusa Tenggara I, 2015).

Mengingat belum adanya pedoman operasi pada Embung Tiu Pasai, maka perlu adanya kajian untuk menentukan lepasan yang dianggap paling optimal. Kajian pada studi ini difokuskan pada optimasi lepasan berdasarkan tampungan guna meningkatkan kebutuhan irigasi dan mampu menyuplai air baku.

Algoritma genetik telah diakui sebagai teknik yang efektif untuk menyelesaikan masalah pengoptimalan. Algoritma Genetik dimulai dengan populasi yang dihasilkan secara acak, dan kemajuan menuju populasi yang lebih baik dengan menerapkan operator genetik yang dimodelkan pada proses genetik yang terjadi di alam (A. Ayman., 2011).

Maka dari permasalahan di atas dapat digunakan sebagai penelitian dengan judul "Simulasi Pola Operasi Fungsi Tampungan Embung Tiu Pasai Sebagai Suplai Air Baku Di Kecamatan Lape Menggunakan Metode Algoritma Genetik" dan diharapkan dapat memberi gambaran tentang peningkatan keberhasilan dalam produksi untuk Kabupaten Sumbawa dan sekitarnya.

\section{METODOLOGI \\ Lokasi Studi}

Lokasi Embung Tiu Pasai terdapat pada DAS Nangabangka (No. 055) dengan luas 12 $\mathrm{km}^{2}$. DAS Nangabangka berada pada koordinat $08^{\circ} 34^{\prime} 32.89^{\prime \prime}$ LS - $08^{\circ} 41^{\prime} 2.87^{\prime \prime}$ LS dan $117^{\circ}$ $33^{\prime} 48.34^{\prime \prime}$ BT $-117^{\circ} 41^{\prime} 27.04^{\prime \prime}$ BT.

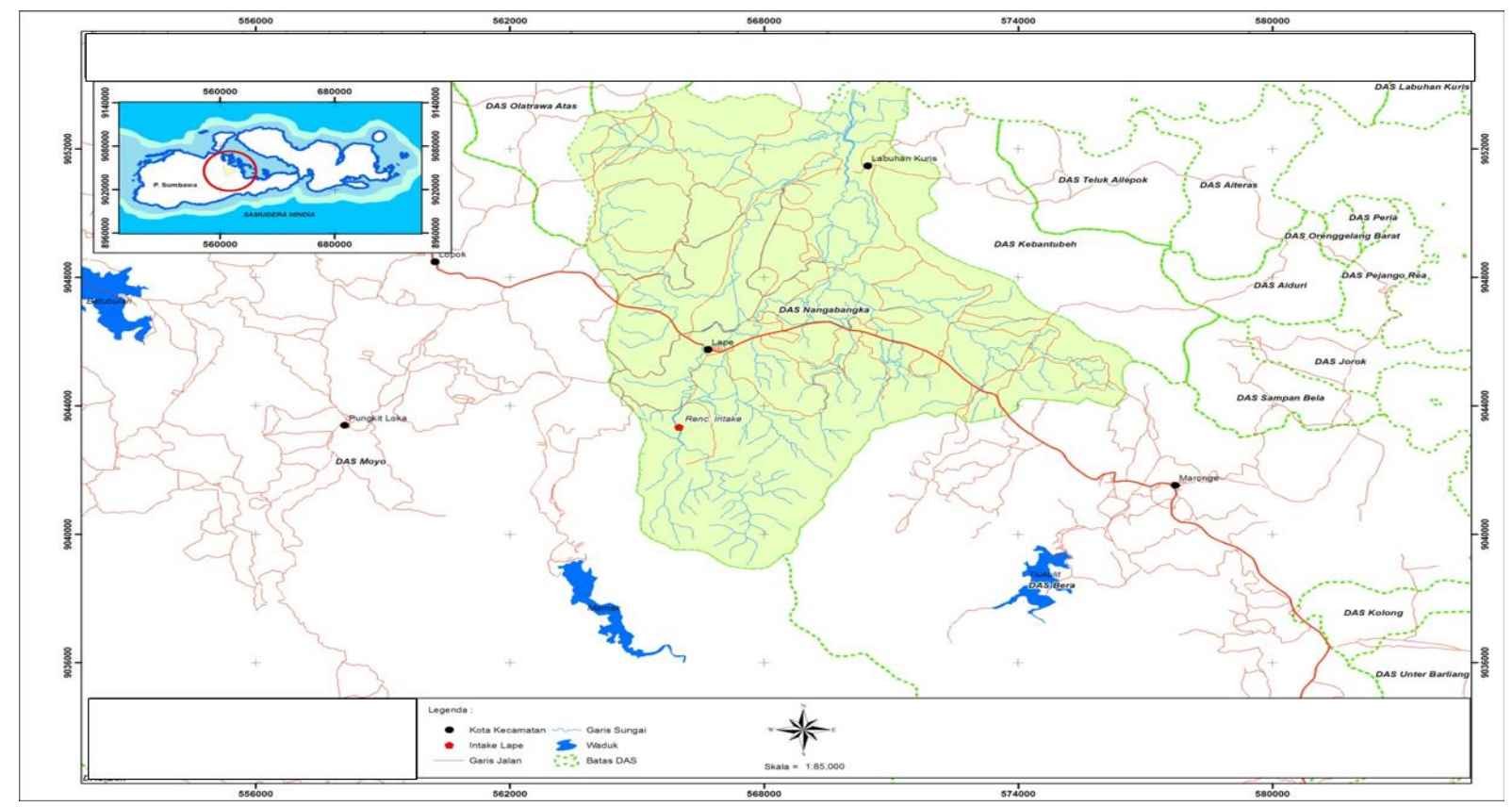

Gambar 1. Peta Lokasi Studi

Sumber: Balai Wilayah Sungai Nusa Tenggara I (2015)

\section{Pengumpulan Data}

Data yang digunakan merupakan data sekunder, antara lain:

1. Hasil pengukuran Luas Genangan, Gambar Desain Embung Tiu Pasai

2. Data Teknis Embung

3. Data Hidrologi Dan Klimatologi

4. Data pendukung lain yang relevan.

\section{Pengolahan Data}

Secara garis besar proses pengembangan kromosom dengan genetic algorithm terdiri dari 3 komponen (Goldberg, 1989). Adapun Prosedur Dalam Simulasi waduk berdasarkan Lepasan, sebagai berikut:

1. Reproduksi

Reproduksi adalah proses seleksi terhadap kromosom yang terdapat pada suatu populasi berdasarkan nilai kinerja dari masing-masing 
kromosom dan dilanjutkan dengan proses copy ini merupakan generasi turunan yang berikutnya.

Inisialisasi algoritma membutuhkan set parameter sebagai generasi populasi awal, yang kemudian berevolusi sesuai dengan algoritma (Boisvert Jasmin, El-Jabi1 Nassir, St-Hilaire André, El Adlouni Salah-Eddine., 2016).

Pada proses Reproduksi maka dibangkitkan secara stokastik populasi pertama sebanyak 16 kromosom (Alternatif Aturan Lepasan).

Satu kromosom dibangkitkan melalui dua tahap yaitu:

1. 5000 Iterasi awal

2. 1000 Iterasi lanjutan dengan kisaran acak $0,3000-0,0005$

Pada proses Inisialisasi (Reproduksi), populasi awal dan iterasi diperbanyak sehingga menghasilkan solusi yang lebih baik lagi yang mempunyai nilai kinerja lebih baik.

Dalam Penelitian ini dijalankan sepuluh kali untuk memperoleh solusi optimal dari setiap model optimal Algoritma. Karena untuk setiap kisaran pencarian harus diterapkan batas iterasi maksimum. batas maksimum tersebut adalah Iter_Awal $=50 \times$ Iter_Lanj $=10 \times$ Iter_Lanj $=$ $10=5000$ iterasi.

Berikut adalah subprogram dalam perhitungan simulasi generasi awal:

\begin{tabular}{|c|}
\hline Program Ms. Excel-VBA (Visual Basic for Application) \\
\hline Sub A1_Simulasi_Acak_Generasi_Awal() \\
\hline Calculate \\
\hline With Worksheets("Penel_OP_Wdk_1") \\
\hline Iter_Awal $=50$ \\
\hline Iter_Lanj $=10$ \\
\hline Iter_Kisr $=10$ \\
\hline .Range("BU3:DR60").ClearContents \\
\hline .Range("BBS3:BDP22").ClearContents \\
\hline For $\mathrm{G}=1$ To 16 \\
\hline .Range("AX8:AZ8").ClearContents \\
\hline Range("AX12:AZ21").ClearContents \\
\hline Range("BB5"). Value $=0$ \\
\hline Range("BD1").Value $=1$ \\
\hline N_improv $=0$ \\
\hline For $\mathrm{i}=1$ To Iter_Awal \\
\hline .Range("AX8"). Value = i \\
\hline .Calculate \\
\hline If .Range("BF5").Value $=0$ Then \\
\hline. Range("BB5"). Value = .Range("BD5"). Value \\
\hline .Range("BB12:BB32").Value = .Range("BD12:BD32").Value \\
\hline N_improv $=$ N_improv +1 \\
\hline .Range("AY8").Value = N_improv \\
\hline .Range("AZ8").Value = .Range("BD5").Value \\
\hline End If \\
\hline
\end{tabular}

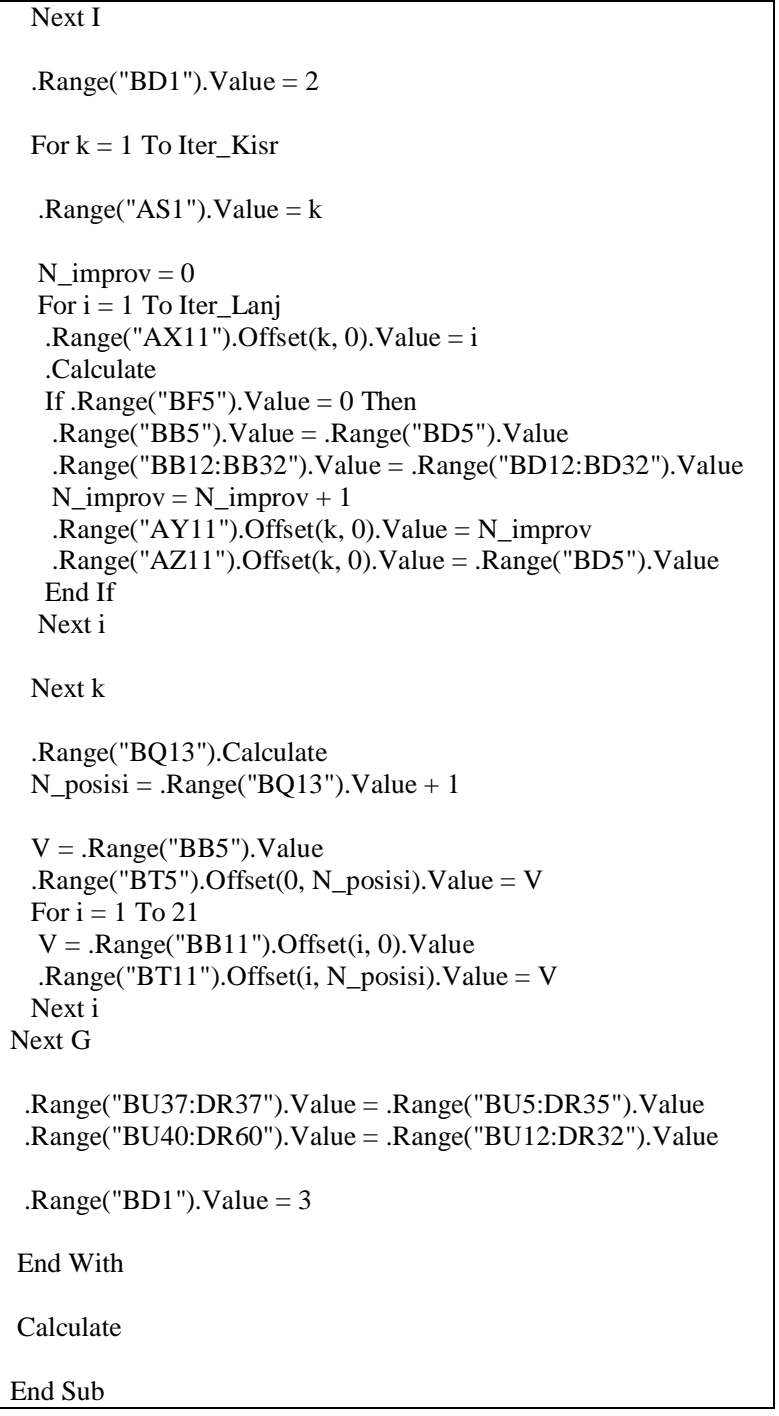

2. Crossover

Crossover adalah persilangan diantara kromosom-kromosom yang ada pada generasi turunan. Pada persilangan ini, setiap variabel kromosom baru merupakan gabungan antara dua variabel dari kedua kromosom generasi turunan. Untuk variabel ke I, maka rumus stokastik penggabungan sebagai berikut:

$\mathrm{Vi}=\mathrm{V} 1 \mathrm{i} . \mathrm{U}[0,1]+\mathrm{V} 2 \mathrm{i} \cdot(1-\mathrm{U}[0,1])$

Dengan Vi adalah variabel dari kromosom baru gabungan, V1i dan V2i adalah varibel masing-masing dari kedua kromosom generasi turunan, dan $\mathrm{U}[0,1]$ adalah bilangan acak uniform antara 0 dan 1 . Berikut adalah subprogram dalam Perintah yang dijalankan dari sub program C_Crossover() untuk persilangan antara 16 kromosom menghasilkan data populasi: 
Program Ms. Excel-VBA (Visual Basic for Application) Sub B1_Crossover()

Calculate

With Worksheets("Penel_OP_Wdk_1")

.Range("BD1").Value $=3$

I_populasi = .Range("DW2").Value

I_cross = .Range("DW6").Value

.Range("EH3:AZJ5").ClearContents

.Range("EH9:AZJ9").ClearContents

.Range("EH12:AZJ32").ClearContents

For I_p = 1 To I_populasi

.Range("DW1").Value = I_p

Ada_Perbaikan $=0$

.Calculate

Nilai_1 = .Range("DZ5").Value

Nilai_2 = .Range("EA5").Value

If Nilai_1 <= Nilai_2 Then

.Range("ED3:ED5").Value = .Range("DZ3:DZ5").Value

.Range("ED12:ED32").Value = . Range("DZ12:DZ32").Value Else

.Range("ED3:ED5").Value = .Range("EA3:EA5").Value

.Range("ED12:ED32").Value = .Range("EA12:EA32"). Value End If

For I_c = 1 To I_cross

.Calculate

If $\cdot$ Range("EA8").Value $=0$ Then

Range("ED3:ED5").Value = .Range("EC3:EC5").Value

.Range("ED12:ED32").Value = .Range("EC12:EC32").Value Ada_Perbaikan $=1$

End If

Next I_c

.Range("EG3").Offset(0, I_p).Value = .Range("ED3").Value .Range("EG4").Offset(0, I_p).Value = .Range("ED4").Value .Range("EG5").Offset(0, I_p).Value = .Range("ED5").Value

.Range("EG9").Offset(0, I_p).Value = Ada_Perbaikan

For prd = 1 To 21

.Range("EG11").Offset(prd, I_p).Value =

Range("ED11").Offset(prd, 0).Value

Next prd

Next I_p

End With

Calculate

End Sub

Perintah yang dijalankan dari sub program C_Crossover() untuk persilangan antara 16 kromosom menghasilkan data populasi.

3. Mutasi

Mutasi adalah perubahan yang terjadi diantara variabel-variabel dari kromosom. Optimasi Genetic Algorithm terutama dilakukan oleh reproduksi dan crossover secara bergantian menghasilkan generasi turunan dari kromosom yang semakin baik dan juga semakin homogeny (Soetopo, 2012).

\section{HASIL DAN PEMBAHASAN}

Proses sumulasi Algoritma Genetik ini berlangsung secara iteratif dengan menghitung secara langsung kinerja kromosom (alternatif aturan lepasan) pada Embung Tiu Pasai selama 10 tahun (2005-2014) dengan meninjau pemenuhan kebutuhan minimum untuk air baku dan irigasi sebagai fungsi tujuan.

Model optimasi Algoritma Genetika adalah proses optimasi yang secara iteratif mengembangkan dari suatu populasi (kromosom-kromosom) daripada kromosom (alternatif lepasan waduk) sehingga tercapailah suatu kumpulan variabel lepasan waduk yang homogen (seragam) daripada variabel lepasan waduk yang terbaik.

Contoh aturan lepasan berdasarkan tampungan dapat dilihat pada Tabel 1 berikut:

Tabel 1. Contoh Aturan Lepasan Berdasarkan Tampungan Pada Simulasi Algortima Genetik mencakup populasi, kromosom, dan Gen

\begin{tabular}{|c|c|c|c|c|c|c|c|c|}
\hline $\begin{array}{l}\text { Tampungan } \\
\text { Waduk }\end{array}$ & & & & $\begin{array}{c}\text { asan Wad } \\
{[\%]}\end{array}$ & & & & $\begin{array}{c}\text { Populasi } \\
\text { Sekumpulan Alternatif }\end{array}$ \\
\hline$[\%]$ & 1 & 2 & 3 & 4 & 5 & - & 16 & Aturan Lepasan \\
\hline 0.00 & 4.81 & 2.38 & 5.49 & 5.86 & 3.69 & - & 5.89 & outflow Berdasarkan \\
\hline 5.00 & 5.05 & 6.31 & 5.68 & 6.04 & 4.90 & - & 6.10 & \\
\hline 10.00 & 5.88 & 15.58 & 6.48 & 6.59 & 7.46 & - & 7.38 & \\
\hline 15.00 & 9.92 & 16.36 & 7.29 & 6.94 & 11.89 & - & 7.54 & \\
\hline 20.00 & 15.94 & 22.72 & 13.31 & 13.30 & 18.38 & - & 12.87 & \\
\hline 25.00 & 19.17 & 26.61 & 19.16 & 20.38 & 26.82 & - & 17.33 & \\
\hline 30.00 & 25.97 & 33.11 & 26.73 & 23.02 & 31.62 & - & 22.31 & Kromosom \\
\hline 35.00 & 30.35 & 38.22 & 30.47 & 31.61 & 32.83 & - & 26.27 & (Alternatif Solusi \\
\hline 40.00 & 33.96 & 39.73 & 36.70 & 39.43 & 37.34 & - & 29.04 & Alternatif Aturan \\
\hline 45.00 & 40.39 & 47.95 & 41.72 & 45.65 & 41.27 & - & 35.66 & $\begin{array}{l}\text { Lepasant } \\
\text { outflow/Variabel }\end{array}$ \\
\hline 50.00 & 46.72 & 52.02 & 50.67 & 51.94 & 47.07 & - & 38.70 & Keputusan) \\
\hline 55.00 & 55.37 & 54.73 & 52.66 & 55.53 & 51.60 & - & 43.77 & \\
\hline 60.00 & 59.03 & 54.83 & 61.24 & 62.56 & 56.78 & - & 53.59 & \\
\hline 65.00 & 66.80 & 62.88 & 69.19 & 70.64 & 58.31 & - & 61.31 & \\
\hline 70.00 & 71.05 & 68.62 & 73.43 & 73.52 & 63.86 & - & 68.38 & \\
\hline 75.00 & 74.13 & 73.87 & 78.13 & 81.28 & 72.57 & - & 75.04 & $\mathrm{Cen} / \mathrm{V}$ \\
\hline 80.00 & 81.22 & 80.83 & 83.61 & 81.58 & 79.42 & - & 81.28 & (Satu Aturan Lepasan, \\
\hline 85.00 & 88.49 & 83.24 & 88.89 & 89.06 & 84.17 & - & 87.32 & Berdasarkan Kondisi \\
\hline 90.00 & 94.61 & 83.25 & 91.43 & 92.70 & 86.78 & - & 96.50 & Tampungan Tertentu, \\
\hline 95.00 & 96.59 & 90.66 & 93.33 & 95.97 & 95.11 & - & 97.75 & \\
\hline 100.00 & 100.00 & 100.00 & 100.00 & 100.00 & 100.00 & - & 100.00 & \\
\hline
\end{tabular}

Sumber: Perhitungan 


\section{Reproduksi}

Dalam penentuan nilai kinerja (ranking), semakin besar nilai fungsi tujuan maka semakin baik kinerja dari kromosom tersebut. Kemudian dilanjutkan dengan proses copy, proses copy atau proses pemilihan generasi terbaik ini akan menjadi generasi turunan.berikutnya. Proses seleksi disini memilih 16 variabel lepasan waduk terbaik (diranking) dari kumpulan variabel aturan lepasan waduk yang berjumlah 120 .

Tabel 1. Hasil Bangkitan Populasi Awal dari Proses Inisialisasi

\begin{tabular}{|c|c|c|c|c|c|c|c|c|c|}
\hline No. & 1 & 2 & 3 & 4 & 5 & 6 & 7 & - & 120 \\
\hline Kinerja & 8.77 & 8.79 & 8.8 & 8.78 & 8.79 & 8.81 & 8.78 & - & 8.72 \\
\hline $\begin{array}{c}\text { Lepasan Waduk } \\
\text { Wadungan }\end{array}$ & \multicolumn{9}{|c|}{$[\%]$} \\
\hline$[\%]$ & 1 & 2 & 3 & 4 & 5 & 6 & 7 & - & 120 \\
\hline 0.00 & 8.77 & 8.79 & 8.80 & 8.78 & 8.79 & 8.81 & 8.78 & - & 8.72 \\
\hline 5.00 & 9.09 & 4.83 & 9.11 & 9.10 & 9.12 & 9.12 & 9.09 & - & 9.11 \\
\hline 10.00 & 9.57 & 7.27 & 9.56 & 9.58 & 9.57 & 9.60 & 9.57 & - & 9.56 \\
\hline 15.00 & 9.94 & 5.34 & 9.89 & 9.92 & 9.93 & 9.95 & 9.90 & - & 9.91 \\
\hline 20.00 & 10.31 & 5.81 & 10.23 & 10.29 & 10.29 & 10.30 & 10.25 & - & 10.30 \\
\hline 25.00 & 11.45 & 18.37 & 11.43 & 11.49 & 11.48 & 11.48 & 11.56 & - & 11.45 \\
\hline 30.00 & 13.26 & 29.25 & 13.34 & 13.28 & 13.30 & 13.32 & 13.61 & - & 13.05 \\
\hline 35.00 & 16.62 & 54.40 & 16.76 & 16.70 & 16.69 & 16.51 & 16.99 & - & 16.31 \\
\hline 40.00 & 22.56 & 81.70 & 21.91 & 22.49 & 22.06 & 21.38 & 21.70 & - & 21.38 \\
\hline 45.00 & 29.61 & 109.09 & 29.16 & 29.30 & 29.60 & 28.86 & 29.27 & - & 28.27 \\
\hline 50.00 & 36.50 & 120.75 & 36.62 & 36.73 & 37.11 & 36.54 & 36.55 & - & 35.78 \\
\hline 55.00 & 40.90 & 65.36 & 40.98 & 41.06 & 41.54 & 41.34 & 40.81 & - & 39.96 \\
\hline 60.00 & 50.13 & 143.30 & 50.33 & 49.80 & 50.47 & 50.23 & 50.34 & - & 49.51 \\
\hline 65.00 & 59.59 & 147.51 & 59.81 & 59.26 & 59.95 & 59.77 & 59.82 & - & 58.75 \\
\hline 70.00 & 65.52 & 89.98 & 65.65 & 64.94 & 65.90 & 65.58 & 65.58 & - & 64.65 \\
\hline 75.00 & 73.85 & 124.88 & 73.61 & 73.85 & 73.38 & 73.57 & 73.51 & - & 72.58 \\
\hline 80.00 & 76.48 & 42.32 & 76.83 & 76.49 & 76.13 & 76.27 & 76.36 & - & 74.52 \\
\hline 85.00 & 84.01 & 117.62 & 84.30 & 84.17 & 83.73 & 83.85 & 83.74 & - & 82.07 \\
\hline 90.00 & 90.01 & 96.96 & 90.42 & 90.50 & 89.98 & 90.06 & 90.07 & - & 89.20 \\
\hline 95.00 & 93.83 & 54.09 & 93.82 & 93.83 & 93.50 & 93.63 & 93.78 & - & 93.06 \\
\hline 100.00 & 100.00 & 100.00 & 100.00 & 100.00 & 100.00 & 100.00 & 100.00 & - & 100.00 \\
\hline Sumber: hasil perhitungan & han & & & & \\
\hline
\end{tabular}

Berdasarkan Tabel 2, dari 120 kromosom tersebut pada satu generasi populasi, tiap-tiap kromosom memiliki nilai kinerja terhadap fungsi tujuan. Berdasarkan fungsi kinerja tersebut akan di seleksi menjadi 16 kromosom terpilih yang memiliki kinerja terbaik pada suatu populasi.

Dalam proses reproduksi dari 16 kromosom diatas akan dijadikan generasi turunan selanjutnya dengan melalui proses crossover, berhenti ketika antar kromosom homogen.

\section{Proses Crossover Algoritma Genetik}

Selanjutnya adalah proses crossover atau persilangan antar alternatif lepasan. Dari hasil saling menyilangkan alternatif lepasan tersebut terbentuk sebuah populasi dengan jumlah 120 alternatif lepasan hasil kombinasi generasi awal yang berjumlah 16 alternatif lepasan. Persilangan antara dua kromosom generasi turunan akan menghasilkan satu kromosom baru. Berikut hasil dari proses Crossover dapat dilihat pada Tabel 3:
Tabel 3. Tabel Proses Crossover

\begin{tabular}{|c|c|c|c|c|}
\hline Kromosom & Kromosom & Bil. & Kromosom \\
\hline$V_{2} i$ & 1 & 2 & Acak & Gabung \\
\hline & 0.580803 & 0.580986 & 0.3643 & 0.580920 \\
\hline & 0.037511 & 0.018870 & 0.2488 & 0.023509 \\
\hline & 0.009087 & 0.076381 & 0.4175 & 0.048285 \\
\hline 0.147012 & 0.064422 & 0.6368 & 0.117012 \\
\hline 0.506103 & 0.608814 & 0.8120 & 0.525411 \\
\hline 0.513910 & 0.280960 & 0.6230 & 0.426097 \\
\hline 0.613346 & 0.674779 & 0.8934 & 0.619892 \\
\hline 0.715033 & 0.654773 & 0.5382 & 0.687206 \\
\hline 0.687006 & 0.641635 & 0.4889 & 0.663816 \\
\hline 0.283581 & 0.643858 & 0.8674 & 0.331347 \\
\hline 0.405741 & 0.453098 & 0.4275 & 0.432853 \\
\hline 0.618523 & 0.724303 & 0.2634 & 0.696442 \\
\hline 0.715893 & 0.908838 & 0.0653 & 0.896234 \\
\hline 0.698077 & 0.400397 & 0.7549 & 0.625111 \\
\hline 0.410014 & 0.804794 & 0.2699 & 0.698225 \\
\hline 0.205490 & 0.112102 & 0.9401 & 0.199893 \\
\hline 0.506731 & 0.419596 & 0.1678 & 0.434213 \\
\hline 0.928297 & 0.313039 & 0.1834 & 0.425862 \\
\hline 0.814431 & 0.287697 & 0.0242 & 0.300444 \\
\hline 0.533806 & 0.697569 & 0.4634 & 0.621681 \\
\hline
\end{tabular}

Sumber: hasil perhitungan 


$$
\begin{aligned}
& V i=V_{1} i \times U[0.1]+V_{2} i \times(1-U[0.1]) \\
& V i=0.58 \times 0.36+0.58 \times(1-0.36) \\
& V i=0.58
\end{aligned}
$$

Dengan Vi adalah variabel dari kromosom baru gabungan atau variasi dari alternatif lepasan outflow, $\mathrm{V}_{1} \mathrm{i}$ dan $\mathrm{V}_{2} \mathrm{i}$ adalah varibel masing-masing dari kedua alternatif lepasan outflow (kromosom) generasi turunan sebelumnya, dan $\mathrm{U}[0,1]$ adalah bilangan acak uniform antara 0 dan 1.

Jadi semua variabel Vi dari sebuah kromosom baru dibentuk dengan persamaan diatas, maka pembentukan alternatif lepasan baru dilakukan oleh setiap pasangan yang berbeda dari alternatif lepasan generasi turunan (16 alternatif lepasan/kromosom) sehingga terbentuklah 120 alternatif lepasan untuk generasi berikutnya.

\section{Proses Perbaikan}

Proses reproduksi pada proses perbaikan ini melaksanakan peningkatan kualitas dengan melakukan seleksi terhadap populasi alternatif lepasan. Populasi yang terdiri dari 120 alternatif lepasan diseleksi bedasarkan ranking dari nilai kinerja dari setiap alternatif lepasan.

Pada proses perbaikan pada tiap alternatif lepasan perbaikan minimal 1 kali. Dari 120 alternatif lepasan dipilih 16 kromosom terbaik untuk menghasilkan turunan berikutnya.

Alternatif lepasan (kromosom) perbaikan yang terpilih menjadi generasi turunan variabel aturan lepasan dapat dilihat pada Tabel

\begin{tabular}{|c|c|c|c|c|c|c|c|c|c|c|c|c|c|c|c|c|}
\hline No. & 1 & 2 & 3 & 4 & 5 & 6 & 7 & 8 & 9 & 10 & 11 & 12 & 13 & 14 & 15 & 16 \\
\hline Posisi & 10 & 11 & 12 & 13 & 14 & 15 & 24 & 25 & 26 & 27 & 28 & 29 & 37 & 38 & 39 & 40 \\
\hline Kinerja & 3.88 & 8.88 & 8.88 & 8.88 & 8.88 & 8.88 & 8.88 & 8.88 & 8.88 & 8.88 & 8.88 & 8.88 & 8.88 & 8.88 & 8.88 & 8.88 \\
\hline Tampungan & \multirow{2}{*}{\multicolumn{16}{|c|}{$\begin{array}{c}\text { Lepasan Waduk } \\
{[\%]} \\
\end{array}$}} \\
\hline Waduk [\%] & & & & & & & & & & & & & & & & \\
\hline 0.00 & 8.88 & 8.88 & 8.88 & 8.88 & 8.88 & 8.88 & 8.88 & 8.88 & 8.88 & 8.88 & 8.88 & 8.88 & 8.88 & 8.88 & 8.88 & 8.88 \\
\hline 5.00 & 9.19 & 9.19 & 9.19 & 9.19 & 9.19 & 9.19 & 9.19 & 9.19 & 9.19 & 9.19 & 9.19 & 9.19 & 9.19 & 9.19 & 9.19 & 9.19 \\
\hline 10.00 & 9.62 & 9.62 & 9.62 & 9.62 & 9.62 & 9.62 & 9.62 & 9.62 & 9.62 & 9.63 & 9.62 & 9.62 & 9.62 & 9.62 & 9.62 & 9.62 \\
\hline 15.00 & 9.98 & 9.98 & 9.98 & 9.98 & 9.98 & 9.98 & 9.98 & 9.98 & 9.98 & 9.98 & 9.98 & 9.98 & 9.97 & 9.98 & 9.98 & 9.97 \\
\hline 20.00 & 10.33 & 10.33 & 10.33 & 10.33 & 10.33 & 10.33 & 10.33 & 10.33 & 10.33 & 10.33 & 10.33 & 10.33 & 10.33 & 10.32 & 10.33 & 10.33 \\
\hline 25.00 & 11.53 & 11.52 & 11.53 & 11.52 & 11.53 & 11.53 & 11.53 & 11.52 & 11.52 & 11.53 & 11.52 & 11.52 & 11.52 & 11.52 & 11.52 & 11.52 \\
\hline 30.00 & 13.28 & 13.29 & 13.28 & 13.27 & 13.28 & 13.27 & 13.29 & 13.29 & 13.29 & 13.29 & 13.29 & 13.28 & 13.29 & 13.29 & 13.29 & 13.30 \\
\hline 35.00 & 16.50 & 16.52 & 16.50 & 16.50 & 16.50 & 16.50 & 16.51 & 16.52 & 16.52 & 16.51 & 16.51 & 16.51 & 16.51 & 16.53 & 16.52 & 16.52 \\
\hline 40.00 & 21.36 & 21.37 & 21.35 & 21.35 & 21.35 & 21.34 & 21.37 & 21.38 & 21.37 & 21.37 & 21.36 & 21.36 & 21.38 & 21.38 & 21.37 & 21.38 \\
\hline 45.00 & 28.75 & 28.77 & 28.71 & 28.73 & 28.75 & 28.76 & 28.80 & 28.80 & 28.74 & 28.76 & 28.76 & 28.79 & 28.76 & 28.78 & 28.74 & 28.75 \\
\hline 50.00 & 36.46 & 36.42 & 36.42 & 36.45 & 36.45 & 36.45 & 36.52 & 36.48 & 36.46 & 36.48 & 36.47 & 36.50 & 36.47 & 36.44 & 36.46 & 36.47 \\
\hline 55.00 & 41.12 & 41.05 & 41.07 & 41.11 & 41.11 & 41.10 & 41.19 & 41.11 & 41.13 & 41.15 & 41.15 & 41.16 & 41.09 & 41.04 & 41.05 & 41.03 \\
\hline 60.00 & 50.33 & 50.32 & 50.34 & 50.36 & 50.30 & 50.36 & 50.29 & 50.30 & 50.30 & 50.32 & 50.30 & 50.31 & 50.29 & 50.28 & 50.28 & 50.27 \\
\hline 65.00 & 59.92 & 59.90 & 59.92 & 59.94 & 59.89 & 59.94 & 59.87 & 59.89 & 59.88 & 59.90 & 59.88 & 59.89 & 59.87 & 59.86 & 59.86 & 59.85 \\
\hline 70.00 & 65.88 & 65.87 & 65.89 & 65.90 & 65.88 & 65.89 & 65.81 & 65.83 & 65.84 & 65.84 & 65.85 & 65.82 & 65.84 & 65.84 & 65.84 & 65.81 \\
\hline 75.00 & 73.69 & 73.70 & 73.70 & 73.72 & 73.72 & 73.72 & 73.62 & 73.66 & 73.64 & 73.64 & 73.68 & 73.65 & 73.68 & 73.71 & 73.64 & 73.68 \\
\hline 80.00 & 76.16 & 76.15 & 76.18 & 76.18 & 76.18 & 76.16 & 76.10 & 76.12 & 76.11 & 76.11 & 76.15 & 76.11 & 76.16 & 76.17 & 76.14 & 76.17 \\
\hline 85.00 & 83.59 & 83.58 & 83.60 & 83.60 & 83.62 & 83.58 & 83.56 & 83.56 & 83.57 & 83.54 & 83.59 & 83.59 & 83.58 & 83.61 & 83.57 & 83.59 \\
\hline 90.00 & 89.80 & 89.79 & 89.81 & 89.81 & 89.82 & 89.79 & 89.77 & 89.77 & 89.78 & 89.75 & 89.80 & 89.80 & 89.79 & 89.82 & 89.77 & 89.79 \\
\hline 95.00 & 93.55 & 93.58 & 93.58 & 93.55 & 93.56 & 93.56 & 93.55 & 93.55 & 93.58 & 93.55 & 93.55 & 93.57 & 93.56 & 93.57 & 93.59 & 93.56 \\
\hline 100.00 & 100.00 & 100.00 & 100.00 & 100.00 & 100.00 & 100.00 & 100.00 & 100.00 & 100.00 & 100.00 & 100.00 & 100.00 & 100.00 & 100.00 & 100.00 & 100.00 \\
\hline
\end{tabular}
Berikut:

Tabel 4. Populasi Hasil Perbaikan (seleksi) pada reproduksi ke 13

\section{Sumber : Hasil Perhitungan}

Dari 120 alternatif lepasan (kromosom) hasil pada populasi sebelumnya didapatkan 16 alternatif lepasan dengan kinerja terbaik yang kemudian dilakukan copy untuk menghasilkan generasi turunan berikutnya sekaligus agar bisa melihat hasil dari masing-masing dari nilai kinerja alternatif lepasan pada setiap generasi.

Jika alternatif lepasan pada suatu populasi sudah homogen maka dianggap alternatif aturan lepasan tersebut sudah optimal. Untuk memeriksa apakah kumpulan alternatif lepasan (populasi dari kromosom) tersebut seragam (homogen) atau tidaknya dengan menghitung nilai dari alternatif aturan lepasan terbesar dikurangi dengan nilai alternatif aturan lepasan terkecil. Dengan syarat pengurangan antar jenis parameter yang sama. 


\section{Contoh perhitungan:}

Pada kondisi tampungan embung 30\%, nilai terbesar adalah $13.30 \%$ pada alternatif lepasan (kromosom) keenam belas dan terkecil adalah $13.27 \%$ salah pada kromosom ke empat. Maka selisih nilai keduanya: $13.30-$ $13.27=0.02($ Homogen $)$
Besarnya selisih antar kedua jenis variabel menandakan bahwa populasi alternatif lepasan pada generasi turunan berikutnya sudah seragam atau homogen, Untuk hasil perhitungan keseragaman alternatif aturan lepasan disajikan dalam tabel berikut:

Tabel 2. Cek Kondisi Homogen (seragam) Pada Proses Perbaikan Generasi ke 13

\begin{tabular}{|c|c|c|c|c|c|c|c|c|c|c|c|c|c|c|c|c|c|}
\hline No. & 1 & 2 & 3 & 4 & 5 & 6 & 7 & 8 & 9 & 10 & 11 & 12 & 13 & 14 & 15 & 16 & \multirow{5}{*}{$\begin{array}{c}\text { Kondisi } \\
\text { Homogen }\end{array}$} \\
\hline Posisi & 10 & 11 & 12 & 13 & 14 & 15 & 24 & 25 & 26 & 27 & 28 & 29 & 37 & 38 & 39 & 40 & \\
\hline Kinerja & 8.88 & 8.88 & 8.88 & 8.88 & 8.88 & 8.88 & 8.88 & 8.88 & 8.88 & 8.88 & 8.88 & 8.88 & 8.88 & 8.88 & 8.88 & 8.88 & \\
\hline Tampungan & \multirow{2}{*}{\multicolumn{16}{|c|}{ Lepasan Waduk }} & \\
\hline Waduk [\%] & & & & & & & & & & & & & & & & & \\
\hline 0.00 & 8.88 & 8.88 & 8.88 & 8.88 & 8.88 & 8.88 & 8.88 & 8.88 & 8.88 & 8.88 & 8.88 & 8.88 & 8.88 & 8.88 & 8.88 & 8.88 & 0.00 \\
\hline 5.00 & 9.19 & 9.19 & 9.19 & 9.19 & 9.19 & 9.19 & 9.19 & 9.19 & 9.19 & 9.19 & 9.19 & 9.19 & 9.19 & 9.19 & 9.19 & 9.19 & 0.00 \\
\hline 10.00 & 9.62 & 9.62 & 9.62 & 9.62 & 9.62 & 9.62 & 9.62 & 9.62 & 9.62 & 9.63 & 9.62 & 9.62 & 9.62 & 9.62 & 9.62 & 9.62 & 0.00 \\
\hline 15.00 & 9.98 & 9.98 & 9.98 & 9.98 & 9.98 & 9.98 & 9.98 & 9.98 & 9.98 & 9.98 & 9.98 & 9.98 & 9.97 & 9.98 & 9.98 & 9.97 & 0.01 \\
\hline 20.00 & 10.33 & 10.33 & 10.33 & 10.33 & 10.33 & 10.33 & 10.33 & 10.33 & 10.33 & 10.33 & 10.33 & 10.33 & 10.33 & 10.32 & 10.33 & 10.33 & 0.01 \\
\hline 25.00 & 11.53 & 11.52 & 11.53 & 11.52 & 11.53 & 11.53 & 11.53 & 11.52 & 11.52 & 11.53 & 11.52 & 11.52 & 11.52 & 11.52 & 11.52 & 11.52 & 0.01 \\
\hline 30.00 & 13.28 & 13.29 & 13.28 & 13.27 & 13.28 & 13.27 & 13.29 & 13.29 & 13.29 & 13.29 & 13.29 & 13.28 & 13.29 & 13.29 & 13.29 & 13.30 & .02 \\
\hline 35.00 & 16.50 & 16.52 & 16.50 & 16.50 & 16.50 & 16.50 & 16.51 & 16.52 & 16.52 & 16.51 & 16.51 & 16.51 & 16.51 & 16.53 & 16.52 & 16.52 & 3 \\
\hline 40.00 & 21.36 & 21.37 & 21.35 & 21.35 & 21.35 & 21.34 & 21.37 & 21.38 & 21.37 & 21.37 & 21.36 & 21.36 & 21.38 & 21.38 & 21.37 & 21.38 & 0.04 \\
\hline 45.00 & 28.75 & 28.77 & 28.71 & 28.73 & 28.75 & 28.76 & 28.80 & 28.80 & 28.74 & 28.76 & 28.76 & 28.79 & 28.76 & 28.78 & 28.74 & 28.75 & 0.09 \\
\hline 50.00 & 36.46 & 36.42 & 36.42 & 36.45 & 36.45 & 36.45 & 36.52 & 36.48 & 36.46 & 36.48 & 36.47 & 36.50 & 36.47 & 36.44 & 36.46 & 36.47 & 0.10 \\
\hline 55.00 & 41.12 & 41.05 & 41.07 & 41.11 & 41.11 & 41.10 & 41.19 & 41.11 & 41.13 & 41.15 & 41.15 & 41.16 & 41.09 & 41.04 & 41.05 & 41.03 & 0.16 \\
\hline 60.00 & 50.33 & 50.32 & 50.34 & 50.36 & 50.30 & 50.36 & 50.29 & 50.30 & 50.30 & 50.32 & 50.30 & 50.31 & 50.29 & 50.28 & 50.28 & 50.27 & 0.09 \\
\hline 65.00 & 59.92 & 59.90 & 59.92 & 59.94 & 59.89 & 59.94 & 59.87 & 59.89 & 59.88 & 59.90 & 59.88 & 59.89 & 59.87 & 59.86 & 59.86 & 59.85 & 0.10 \\
\hline 70.00 & 65.88 & 65.87 & 65.89 & 65.90 & 65.88 & 65.89 & 65.81 & 65.83 & 65.84 & 65.84 & 65.85 & 65.82 & 65.84 & 65.84 & 65.84 & 65.81 & 0.09 \\
\hline 75.00 & 73.69 & 73.70 & 73.70 & 73.72 & 73.72 & 73.72 & 73.62 & 73.66 & 73.64 & 73.64 & 73.68 & 73.65 & 73.68 & 73.71 & 73.64 & 73.68 & 0.10 \\
\hline 80.00 & 76.16 & 76.15 & 76.18 & 76.18 & 76.18 & 76.16 & 76.10 & 76.12 & 76.11 & 76.11 & 76.15 & 76.11 & 76.16 & 76.17 & 76.14 & 76.17 & 0.08 \\
\hline 85.00 & 83.59 & 83.58 & 83.60 & 83.60 & 83.62 & 83.58 & 83.56 & 83.56 & 83.57 & 83.54 & 83.59 & 83.59 & 83.58 & 83.61 & 83.57 & 83.59 & 0.07 \\
\hline 90.00 & 89.80 & 89.79 & 89.81 & 89.81 & 89.82 & 89.79 & 89.77 & 89.77 & 89.78 & 89.75 & 89.80 & 89.80 & 89.79 & 89.82 & 89.77 & 89.79 & 0.07 \\
\hline 95.00 & 93.55 & 93.58 & 93.58 & 93.55 & 93.56 & 93.56 & 93.55 & 93.55 & 93.58 & 93.55 & 93.55 & 93.57 & 93.56 & 93.57 & 93.59 & 93.56 & 0.04 \\
\hline 100.00 & 100.00 & 100.00 & 100.00 & 100.00 & 100.00 & 100.00 & 100.00 & 100.00 & 100.00 & 100.00 & 100.00 & 100.00 & 100.00 & 100.00 & 100.00 & 100.00 & 0.00 \\
\hline
\end{tabular}

Sumber : Hasil Perhitungan

Tabel 3. Rekap Hasil Iterasi Simulasi Metode Algoritma Genetik

\begin{tabular}{|c|c|c|c|c|c|c|c|c|c|c|c|c|c|c|c|c|c|}
\hline REKAP HASIL & No. & 1 & 2 & 3 & 4 & 5 & 6 & 7 & 8 & 9 & 10 & 11 & 12 & 13 & 14 & 15 & 16 \\
\hline Generasi Awa & & 7.27 & 5.89 & 5.86 & 5.49 & 4.81 & 4.48 & 3.79 & 3.78 & 3.78 & \begin{tabular}{|l|}
3.72 \\
\end{tabular} & 3.69 & 3.38 & 3.37 & 3.18 & 2.72 & 228 \\
\hline Generasi Tunnan & 1 & 7.25 & 6.54 & 6.52 & 6.40 & 6.22 & 6.18 & 6.16 & 6.07 & 6.04 & 5.99 & 5.98 & 5.85 & 5.84 & 5.81 & 5.71 & 5.70 \\
\hline Generasi Tunnan & 2 & 7.76 & 7.66 & 7.62 & 7.59 & 7.59 & 7.45 & 7.45 & 7.41 & 7.32 & 7.32 & 7.31 & 7.28 & 7.26 & 7.20 & 7.17 & 7.12 \\
\hline Generasi Tunnan & 3 & 8.11 & 8.07 & 8.06 & 8.03 & 8.00 & 8.00 & 7.97 & 7.97 & 7.96 & \begin{tabular}{|l|}
7.94 \\
\end{tabular} & 7.94 & 7.93 & 7.93 & 7.93 & 7.92 & 7.91 \\
\hline Generasi Tunnan & 4 & 8.46 & 8.43 & 8.42 & 8.42 & 8.41 & 8.41 & 8.40 & 8.40 & 8.40 & 8.40 & 8.40 & 8.39 & 8.38 & 8.38 & 8.37 & 8.37 \\
\hline Generasi Turnanan & 5 & 8.64 & 8.63 & 8.63 & 8.62 & 8.62 & 8.62 & 8.61 & 8.60 & 8.60 & 8.60 & 8.60 & 8.60 & 8.60 & 8.59 & 8.59 & 8.60 \\
\hline Generasi Turunan & 6 & 8.75 & 8.74 & 8.74 & 8.74 & 8.73 & 8.73 & 8.74 & 8.73 & 8.73 & \begin{tabular}{|l|}
8.73 \\
\end{tabular} & 8.73 & 8.72 & 8.72 & 8.72 & 8.72 & 8.72 \\
\hline Generasi Turnan & 7 & 8.81 & 8.81 & 8.80 & 8.80 & 8.80 & 8.80 & 8.80 & 8.80 & 8.79 & \begin{tabular}{|l|}
8.79 \\
\end{tabular} & 8.79 & 8.79 & 8.79 & 8.79 & 8.78 & 8.78 \\
\hline Generasi Tunnan & 8 & 8.84 & 8.84 & 8.84 & 8.83 & 8.83 & 8.83 & 8.83 & 8.82 & 8.82 & \begin{tabular}{|l|}
8.82 \\
\end{tabular} & 8.82 & 8.82 & 8.82 & 8.82 & 8.82 & 8.82 \\
\hline Generasi Tunnan & 9 & 8.86 & 8.86 & 8.86 & 8.85 & 8.85 & 8.85 & 8.85 & 8.85 & 8.85 & 8.85 & 8.85 & 8.85 & 8.85 & 8.85 & 8.85 & 8.85 \\
\hline Generasi Turnan & 10 & 8.87 & 8.87 & 8.87 & 8.87 & 8.87 & 8.87 & 8.87 & 8.87 & 8.87 & 8.87 & 8.86 & 8.86 & 8.86 & 8.86 & 8.86 & 8.86 \\
\hline Generasi Turnan & 11 & 8.88 & 8.88 & 8.88 & 8.88 & 8.88 & 8.88 & 8.88 & 8.88 & 8.88 & \begin{tabular}{|l|}
8.88 \\
\end{tabular} & 8.87 & 8.87 & $\begin{array}{l}8.87 \\
\end{array}$ & 8.87 & 8.87 & 8.87 \\
\hline Generasi Tunnan & 12 & 8.88 & 8.88 & 8.88 & 8.88 & 8.88 & \begin{tabular}{|l|l|} 
& 8.88 \\
\end{tabular} & $8.88 \mid$ & 8.88 & 8.88 & | 8.88 & 8.88 & 8.88 & $\mid 8.88$ & $8.88 \mid$ & 8.88 & 8.88 \\
\hline \multirow{2}{*}{\multicolumn{6}{|c|}{ Sumber : Hasil Perhitungan }} & \multicolumn{4}{|c|}{$\downarrow$} & & & & & & & & \\
\hline & & & & & & \multicolumn{4}{|c|}{ Homogen } & & & & & & & & \\
\hline
\end{tabular}


Iterasi perhitungan simulasi dengan metode Algoritma Genetik ini akan berhenti begitu dicapainya kondisi populasi kromosom yang seragam (homogen). Dalam kondisi ini maka setiap alternatif lepasan identik satu sama lain. Hal ini tercapai karena semakin berlanjutnya iterasi, maka semakin jarang pula terjadi perbaikan dalam proses crossover antar alternatif lepasan.

Apabila tidak terjadi perbaikan dalam proses Crossover antara sepasang alternatif lepasan (kromosom), maka yang tepilih menjadi anggota populasi berikutnya adalah alternatif lepasan yang lebih baik (di antara pasangan tersebut). Karena dalam seleksi kromosom generasi turunan berdasarkan ranking nilai kinerja, maka semakin lama berlanjutnya iterasi, generasi turunan (dan juga populasi) akan semakin didominasi oleh satu jenis alternatif lepasan terbaik saja. Pada akhirnya hanya ada satu jenis alternatif lepasan saja yang seragam, dan sudah tidak dimungkinkan lagi untuk melakukan perbaikan nilai kinerja.

Berdasarkan hasil fungsi tujuan dan alternatif aturan lepasan yang sudah homogen seragam) maka ditetapkan aturan lepasan pada Embung Tiu Pasai berdasarkan Tampungan yang dianggap paling optimal dengan menggunakan metode Algoritma Genetik adalah sebagai berikut:

Tabel 4. Pedoman Lepasan Hasil Simulasi Metode Algoritma Genetik

\begin{tabular}{|c|c|}
\hline $\begin{array}{c}\text { Pct. } \\
\text { Tamp. } \\
{[\%]}\end{array}$ & $\begin{array}{c}\text { Pct. } \\
\text { Kebutuhan } \\
{[\%]}\end{array}$ \\
\hline 0.00 & 8.88 \\
\hline 5.00 & 9.19 \\
\hline 10.00 & 9.62 \\
\hline 15.00 & 9.98 \\
\hline 20.00 & 10.33 \\
\hline 25.00 & 11.52 \\
\hline 30.00 & 13.30 \\
\hline 35.00 & 16.52 \\
\hline 40.00 & 21.38 \\
\hline 45.00 & 28.75 \\
\hline 50.00 & 36.47 \\
\hline 55.00 & 41.04 \\
\hline 60.00 & 50.27 \\
\hline 65.00 & 59.86 \\
\hline 70.00 & 65.83 \\
\hline 75.00 & 73.68 \\
\hline 80.00 & 76.18 \\
\hline 85.00 & 83.60 \\
\hline 90.00 & 89.81 \\
\hline 95.00 & 93.58 \\
\hline 100.00 & 100.00 \\
\hline
\end{tabular}

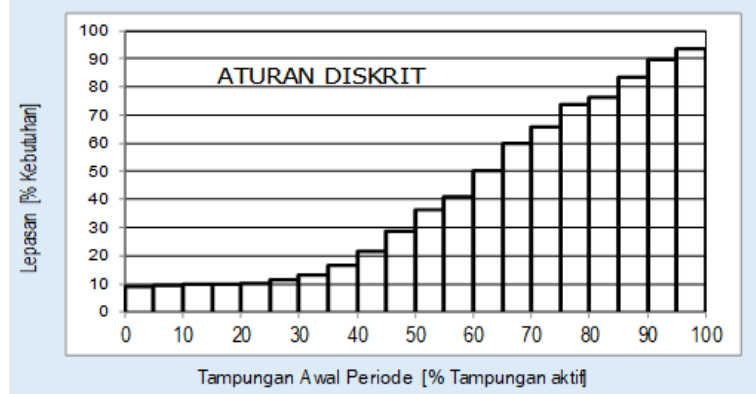

Gambar 2. Grafik Aturan Lepasan

Berdasarkan Tampungan

Berdasarkan Tabel 7 dan Gambar 2, maka apabila tampungan Embung $>95 \%$ dari kapasitas tampungan aktif berarti lepasan sebesar $93.58 \%$ dari kebutuhan. Selanjutnya apabila tampungan Embung $>90 \%$ dari kapasitas tampungan aktif berarti lepasan sebesar $89.81 \%$, dan seterusnya. Apabila Tampungan Embung tepat berada pada batas minimum tampungan Embung, maka lepasan mengikuti lepasan yang sebelumnya. Misalnya tampungan Embung berada pada angka 0\%, maka lepasan sebesar 0\% (bukan 8.88\%).

\section{KESIMPULAN}

Berdasarkan hasil analisa dan pembahaan yang dilakukan dapat dikemukakan hal-hal sebagai berikut:

1. Algoritma Genetik merupakan model simulasi dengan melakukan proses inisialisasi, yaitu pemilihan 16 kromosom (alternatif lepasan). Kemudian secara iteratif dikembangkan lagi melalui proses atau persilangan antar generasi (crossover), terbentuklah 120 kromosom dan memilih 16 kromosom terbaik melalui proses reproduksi. Proses iteratif tersebut akan menghasilkan aturan lepasan yang optimal

2. Dari hasil simulasi, yang terdapat pada Tabel 7 dan Gambar 2 apabila tampungan Embung > 95\% dari kapasitas tampungan aktif, artinya lepasan sebesar $93.58 \%$ dari kebutuhannya dan seterusnya. Apabila Tampungan Embung tepat berada pada batas minimum tampungan Embung, maka lepasan mengikuti lepasan yang sebelumnya.

3. Adanya peningkatan kinerja embung terhadap pemenuhan kebutuhan minimum dari total kebutuhan yang direncanakan dari areal luas irigasi 5 ha menjadi 15 ha dengan intensitas tanam $100 \%$ dan alokasi air baku $20 \mathrm{lt} / \mathrm{dt}$ 


\section{SARAN}

1. Pada proses Inisialisasi, sebaiknya populasi awal dan iterasi diperbanyak sehingga akan menghasilkan solusi yang lebih baik lagi yang mempunyai nilai kinerja lebih baik pula.

2. Sebaiknya dilakukan perbandingan operasi waduk antara menggunakan algoritma genetik dengan operasi waduk secara sederhana namun tetap menggunakan aturan operasi yang jelas.

3. Sangat direkomendasikan menggunakan komputer/ laptop dengan spesifikasi yang tinggi dengan menggunakan processor core i7 untuk mempercepat crossover apabila ingin menambah iterasi yang lebih banyak untuk mendapat nilai solusi yang lebih baik.

\section{DAFTAR PUSTAKA}

A. Ayman., 2011, Optimization of Desiccant Absorption System Using a Genetic Algorithm, Journal of Software Engineering and Applications, 4, 527533

Balai Wilayah Sungai Nusa Tenggara I. 2015, Desain Jaringan Air Baku Tiu Pasai (Ai Mencelik) Di Kecamatan Lape Kabupaten Sumbawa. Mataram: kementerian Pekerjaan Umum

Boisvert Jasmin, El-Jabi1 Nassir, St-Hilaire André, El Adlouni Salah-Eddine., 2016, Parameter Estimation of a Distributed Hydrological Model Using a Genetic Algorithm, Open
Journal of Modern Hydrology, 6, 151167

Goldberg, D.E, 1989. Genetic Algorithm in Search, Optimization, and Machine Learning, Addison Wesley Publishing Company, Inc., Massachusetts.

Karas, I. R. and Umit, A. 2011. A Genetic Algorithm Approach for Findng The Shortest Driving Time On Mobile Devices. Scientific Research and Essays, Vol 6(2), p. 394-405.

Kumar, D.N., Raju, K.S., \& Ashok, B., 2006, Optimal Reservoir Operation for Irrigation of Multiple Crops Using Genetic Algorithms, Journal of Irrigation and Drainage Engineering, 132(2), 123-129.

Nait, 2005. Optimasi Pola Operasi Waduk Tilong dengan Program Dinamik Deterministik. Jurnal yang tidak dipublikasikan.

Soetopo, W., 2007, Penerapan Model SinusPerkalian Pada Rumusan Fungsi Kinerja Irigasi Untuk Optimasi Dengan Program Dinamik, Jurnal Teknik - Fakultas Teknik Universitas Brawijaya 14(2), 97-103

W. C. Wang, C. T. Cheng and D. M. Xu., 2006. The Optimal Operation Model Based on Chaos Genetic Algorithm for Hydropower Station and Its Application, Journal of Hydroelectric Engineering, Vol. 26, No. 6, 2006, pp. 7-11 